\title{
Effectiveness Of Balance Physical Exercise And Muscle Strength About Fall Incident Elderly In Rensing Raya Village, West Sakra District, East Lombok Regency
}

M. Miftahuzzubaidi
Magister of Public Health Program of
Institut Ilmu Kesehatan STRADA
Indonesia
Email:
m.mizzugunn@gmail.com

Received : October 12, 2019

Accepted : February 13, 2020

Published : May 12, 2020

\begin{abstract}
Balance exercise is one of the exercises that can be applied to the elderly. This exercise is a physical activity that is done to improve the stability of the body by increasing muscle strength in the legs. Muscle strength is a driving force for movement in completing tasks and can reduce falls especially for the elderly. A fall event is an event reported by a patient or witness, who sees an incident resulting in a person suddenly lying / sitting on the lower floor / place with or without loss of consciousness or injury. This type of research is quantitative, with a Quasi Experimental research design with a Pretest-Posttest Control Group Design approach. The sampling technique used is non probability sampling: purposive sampling with a sample of 34 respondents. data analysis techniques using paired $t$ test. Based on the results of multivariate analysis paired $t$ test on the fall event variable for the treatment group, the results obtained $p$ value $0.006<0.05$. it means that there is a significant effect after being given the treatment of physical exercise balance and muscle strength on the incidence of falls in the elderly. Whereas in the control group, the result was $\mathrm{p}$ value $0.018<0.05$. it means that there is a significant effect after being given another treatment, namely gymnastics in the elderly towards the event of falling in the elderly. Balance and muscle strength training is very effective in reducing the number of falls in the elderly. Whereas the control group given elderly exercise also had the effectiveness to reduce the incidence of falls in the elderly. In an effort to reduce the incidence of falls, the elderly can do physical exercise balance and muscle strength regularly
\end{abstract}

Keywords: Balance Physical Exercise, Muscle Strength, Fall Incident

\section{cc) (†) (?)}

This is an open-acces article distributed under the terms of the Creative Commons Attribution-ShareAlike 4.0 International License. 


\section{INTRODUCTION}

In Indonesia, it has developed rapidly in development and has created a lot of conditions for improved social communities, especially in increasing life expectancy so that the number of elderly is increasing both in the world and in Indonesia. According to the World Health Organization (2014), the number of elderly people in the world above 60 years in 2000 to 2050 will double from about $11 \%$ to $22 \%$, or increase from 605 million to 2 billion elderly people.

The aging process (aging) is a natural process that is passed by humans during their lives, a dynamic process and complex resulting from cell changes, physiological and psychological. And one of the fundamental changes is a physical change and one of the most common physical changes that occur in the muscululus is the muscle stiffness, weakness of the muscle mass, and osteoporosis that can cause a decrease in muscle strength, endurance, limited range of motion (ROM) (miller), 2012). Muscle weakness can cause disturbance in the body's balance so that it can result in slowness of motion, the foot cannot tread strongly, walk short, and slow to anticipate if there is tripping and falling according to (Tinetti, 1992, Kane, 1994, and Reuben, 1996, Darmojo 2004 , and setyadi in the 2013 nursing journal).

The incidence rate falls in the elderly by $45 \%$ with an average number of events falling once a year. In Indonesia the number of injuries in the population over 55 years reached 22\%, of which $65 \%$ were due to falling events (Riskesdas, 2013). Stevens (2006) explains that $10 \%$ of elderly people who fall cause serious injury. $12.1 \%$ of the elderly had broken bones, $33.3 \%$ were sprained, $45.9 \%$ were bruised, and $8.7 \%$ were others. The most commonly affected body parts are the legs and arms. (Journal of Galia Wardha Alvita 2018).

In principle, preventing falls in the elderly is very important and more important than treating the consequences. To prevent falls requires a physical exercise that can improve the balance and speed of the road. Forms of balance training include aquatic exercise therapy and land exercise therapy. (Javaheri et al, 2012 in the 2015 Budi Utomo journal).

Based on data from the West Nusa Tenggara Province of Aceh, the prevalence of the number of elderly due to injury due to falls and the highest area affected by falling is West Lombok District. The prevalence of falls with ages $45-54$ by $44.4 \%$, ages $55-64$ by $44.5 \%$, ages $65-74$ by $50.0 \%$, and ages $75+$ by $51.8 \%$. by sex, men were more often affected by falls by $11.0 \%$ and women by $7.2 \%$.

From the results of preliminary study observations, it is found that almost every day there are elderly people who experience falls, $15 \%$ of the elderly who fall injured and even sprained. Elderly who are seriously injured due to falling about 8 elderly from 42 elderly. The data is also strengthened by the results of interviews conducted with the elderly who said that the majority of injuries in the legs and arms caused by falling so that the elderly become limited in their activities.

\section{METHODS}

This type of research is quantitative, with the design of this study using Quasi Experimental with the Pretest-Posttest Control Group Design approach. The study was conducted with two groups: the treatment group and the control group. The treatment group was treated with exercise balance and muscle strength for 4 weeks, while the control group was given another treatment that is elderly exercise. The sampling technique used is non probability sampling: purposive sampling with a sample of 34 elderly (60-90 years).

\section{RESULTS \\ Description of Place of Study}

The research location in the village of Rensing Raya which is one of the 18 villages (eighteen) villages in the West Sakra District, is one of the expansion villages of the Rensing village with an area of $190 \mathrm{Ha}$. Or $1.9 \mathrm{Km} 2$, which consists of 4 (Four) Hamlets, namely eastensens hamlet, bimbi hamlet, dangah hut hamlet, mosque hamlet hamlet. This research was carried out in the Bimbi sub-village, rensing raya village, West Sakra sub-district, East Lombok regency, the location of the Bimbi subvillage is in Jl. and the time the study was carried out in October 2019. 


\section{Descriptive Public Data}

Table 1 Distribution Frequency Characteristics of Respondents in rensing raya village 2019.

\begin{tabular}{cccccc}
\hline & & \multicolumn{2}{c}{ Treatment Group } & \multicolumn{2}{c}{ Control Group } \\
\hline No & Characteristic & $(\mathrm{f})$ & $(\%)$ & $(\mathrm{f})$ & $(\%)$ \\
\hline 1 & $60-74$ year & 10 & 58,8 & 8 & 47,1 \\
\hline 2 & $75-90$ year & 7 & 41,2 & 9 & 52,9 \\
\hline & Total & 17 & 100 & 17 & 100 \\
\hline 1 & Male & 3 & 17,6 & 9 & 52,9 \\
\hline 2 & Female & 14 & 82,4 & 8 & 47,1 \\
\hline & Total & 17 & 100 & 17 & 100 \\
\hline 1 & Housewife & 8 & 47,1 & 5 & 29,4 \\
\hline 2 & Farmer & 5 & 29,4 & 4 & 23,5 \\
\hline 3 & Unmployment & 2 & 11,8 & 0 & 0 \\
\hline 4 & marketeer & 2 & 11,8 & 1 & 5,9 \\
\hline 5 & Worker & 0 & 0 & 4 & 23,5 \\
\hline 6 & Officer & 0 & 0 & 1 & 5,9 \\
\hline 7 & Breeder & 0 & 0 & 2 & 11,8 \\
\hline & Total & 17 & 100 & 17 & 100 \\
\hline 1 & $>$ one disease & 14 & 82,4 & 12 & 70,6 \\
\hline 2 & One disease & 3 & 17,6 & 5 & 29,4 \\
\hline & Total & 17 & 100 & 17 & 100 \\
\hline Sour & Pata & & & &
\end{tabular}

Source : Primary Data (2019)

Based on the results of the study of dri table 1 of 17 respondents in the treatment group and 17 respondents in the control group it was found that the age of the elderly in the treatment group that was mostly aged 60-74 years was 10 people (58.8\%) while in the control group the most was age $75-90$ years totaling 9 people $(52.9 \%)$. The sex of the elderly in the treatment group the most were females totaling 14 people $(82.4 \%)$ while in the control group the most were males totaling 9 people $(52.9 \%)$. The work of the elderly in the treatment group the most were housewives totaling 8 people $(47.1 \%)$ while in the control group the most were housewives totaling 5 people $(29.4 \%)$. The history of the elderly disease in the treatment group with the most is more than 1 disease totaling 14 people $(82.4 \%)$ while in the control group the most is more than 1 disease totaling 12 people $(70.6 \%)$.

\section{Custom Data}

Table 2 Distribution Frequency Respondents Based on Special Data in Rensing Raya Village 2019.

\begin{tabular}{ccccccccc}
\hline & \multicolumn{3}{c}{ Treatment Groups } & \multicolumn{4}{c}{ Control Groups } \\
\cline { 2 - 10 } Fall Incident & Pre & $\%$ & Post & $\%$ & Pre & $\%$ & Post & $\%$ \\
\hline No risk (0-24) & 2 & 11,8 & 5 & 29,4 & 3 & $17,6 \%$ & 7 & 41,2 \\
\hline Moderate risk $(25-50)$ & 13 & 76,5 & 12 & 70,6 & 14 & $82,4 \%$ & 10 & 58,8 \\
\hline High risk $(>51)$ & 2 & 11,8 & 0 & 0 & 0 & $0 \%$ & 0 & 0 \\
\hline Total & 17 & 100 & 17 & 100 & 17 & 100 & 17 & 100 \\
\hline
\end{tabular}

Source : Primary Data (2019)

From table 2 above, obtained the frequency distribution of respondents in the treatment group before being given the treatment that experienced the most falls is a moderate risk of 13 people $(76.5 \%)$. whereas after being given the most treatment is in the category of moderate risk to fall totaling 12 people (70.6\%). Whereas in the control group before being given the most treatment, there was a moderate risk of falling by 14 people ( $82.4 \%$ ). And after being given the most treatment is in the medium risk category to experience a fall of 10 people (58.8\%). 


\section{Cross Tabulation}

\section{Age With Fall Incident}

a. Table 3 Cross Tabulation of Age Based Treatment Groups with Falling Events Before and After Treatment of the Elderly in Rensing Raya Village, West Sakra District, East Lombok Regency 2019.

\begin{tabular}{|c|c|c|c|c|c|c|c|c|c|}
\hline \multirow{3}{*}{ Age } & \multicolumn{9}{|c|}{ Fall Event of the Treatment Group } \\
\hline & \multicolumn{5}{|c|}{ Before Treatment } & \multicolumn{4}{|c|}{ After Treatment } \\
\hline & $\begin{array}{c}\text { No } \\
\text { Risk }\end{array}$ & $\begin{array}{l}\text { Moderate } \\
\text { risk }\end{array}$ & $\begin{array}{l}\text { High } \\
\text { Risk }\end{array}$ & Total & $\%$ & $\begin{array}{l}\text { No } \\
\text { Risk }\end{array}$ & $\begin{array}{l}\text { Moderate } \\
\text { risk }\end{array}$ & Total & $\%$ \\
\hline $60-74$ year & 1 & 7 & 2 & 10 & $\begin{array}{c}58 \\
8\end{array}$ & 2 & 8 & 10 & $\begin{array}{c}58, \\
8\end{array}$ \\
\hline $75-90$ year & 1 & 6 & 0 & 7 & $\begin{array}{c}41, \\
2\end{array}$ & 3 & 4 & 7 & $\begin{array}{c}41, \\
2\end{array}$ \\
\hline Total & 2 & 13 & 2 & 17 & 100 & 5 & 12 & 17 & 100 \\
\hline
\end{tabular}

Source : Primary Data (2019)

From table 3 above, it is found that the frequency distribution of respondents in the treatment group prior to being given the most treatment is the elderly aged 10 people (58.8\%) with the category of falls being the most dominant risk being 7 people (41.2\%). Whereas the respondent after being given the most treatment was the elderly at the number of 10 people $(58.8 \%)$ with the category of the most dominant risk of falling being 8 people $(47.1 \%)$.

b. Table 4 Cross Tabulation in Control Groups Based on Age with Falling Events Before and After Treatment of the Elderly in Rensing Raya Village, West Sakra District, East Lombok Regency 2019.

\begin{tabular}{|c|c|c|c|c|c|c|c|c|}
\hline \multirow{3}{*}{ Age } & \multicolumn{8}{|c|}{ Fall Event of the Control Group } \\
\hline & \multicolumn{4}{|c|}{ Before Treatment } & \multicolumn{4}{|c|}{ Before Treatment } \\
\hline & $\begin{array}{c}\text { No } \\
\text { Risk }\end{array}$ & $\begin{array}{c}\text { Modera } \\
\text { te risk }\end{array}$ & Total & $\%$ & $\begin{array}{c}\text { No } \\
\text { Risk }\end{array}$ & $\begin{array}{c}\text { Moderate } \\
\text { risk }\end{array}$ & Total & $\%$ \\
\hline $60-74$ year & 3 & 5 & 8 & $\begin{array}{c}47, \\
1\end{array}$ & 4 & 4 & 8 & $\begin{array}{c}47, \\
1\end{array}$ \\
\hline $75-90$ year & 0 & 9 & 9 & $\begin{array}{c}52 \\
9\end{array}$ & 3 & 6 & 9 & $\begin{array}{c}52 \\
9\end{array}$ \\
\hline Total & 3 & 14 & 17 & 100 & 7 & 10 & 17 & 100 \\
\hline
\end{tabular}

(Source: primary data, highway rensing, 28 October-5 December 2019)

From table 4 above, obtained the frequency distribution of respondents in the control group before being given the treatment that most experienced falls is old age (75-90 years) totaling 9 people $(52.9 \%)$ with the most dominant category being medium risk totaling 9 people $(52.9 \%)$. Whereas the respondent after being given the most treatment was the elderly (75-90 years old) amounting to 9 people (52.9\%) with the category of the most dominant risk of falling being 6 people $(35.2 \%)$.

\section{Gender With Fall Incident}

a. Table 5 Tabulasi Silang Pada Kelompok Perlakuan Berdasarkan Jenis Kelamin Dengan Kejadian Jatuh Sebelum Perlakuan Pada Lansia Di Desa Rensing Raya Kecamatan Sakra Barat Kabupaten Lombok Timur 2019.

\begin{tabular}{|c|c|c|c|c|c|c|c|c|c|}
\hline \multirow{3}{*}{ Gender } & \multicolumn{9}{|c|}{ Fall Event of the Treatment Group } \\
\hline & \multicolumn{5}{|c|}{ Before Treatment } & \multicolumn{4}{|c|}{ Before Treatment } \\
\hline & No risk & $\begin{array}{l}\text { Moderate } \\
\text { risk }\end{array}$ & High risk & Total & $\%$ & No risk & $\begin{array}{l}\text { Moderate } \\
\text { risk }\end{array}$ & Total & $\%$ \\
\hline Male & 0 & 3 & 0 & 3 & $\begin{array}{c}17, \\
6\end{array}$ & 0 & 3 & 3 & $\begin{array}{c}17, \\
6\end{array}$ \\
\hline Female & 2 & 10 & 2 & 14 & $\begin{array}{c}82 \\
4\end{array}$ & 5 & 9 & 14 & $\begin{array}{c}82 \\
4\end{array}$ \\
\hline Total & 2 & 13 & 2 & 17 & 100 & 5 & 12 & 17 & 100 \\
\hline
\end{tabular}


(Source: primary data, highway rensing, 28 October-5 December 2019)

From table 5 above, it is found that the frequency distribution of respondents in the treatment group before being given the most treatment was 14 female (82.4\%) with the most dominant risk falling category being 10 people $(58.8 \%)$. Whereas for the respondents after being given the most treatment, there were 14 female $(82.4 \%)$ with the most dominant risk falling category being $9(52.9 \%)$.

b. Table 6 Cross Tabulation in Control Groups Based on Gender With Falling Events Before and After Treatment of the Elderly in Rensing Raya Village, West Sakra District, East Lombok Regency 2019.

\begin{tabular}{lccccccccc}
\hline & \multicolumn{4}{c}{ Fall Event of the Control Group } \\
\cline { 2 - 9 } Gender & \multicolumn{4}{c}{ Before Treatment } & \multicolumn{5}{c}{ Before Treatment } \\
\cline { 2 - 10 } & No risk $\begin{array}{c}\text { Moderate } \\
\text { risk }\end{array}$ & $\begin{array}{c}\text { High } \\
\text { risk }\end{array}$ & Total & $\%$ & No risk $\begin{array}{c}\text { Moderate Total } \\
\text { risk }\end{array}$ & $\%$ \\
\hline Male & 2 & 7 & 0 & 9 & 52,9 & 3 & 6 & 9 & 52,9 \\
Female & 1 & 7 & 0 & 8 & 47,0 & 4 & 4 & 8 & 47,0 \\
\hline \multicolumn{1}{c}{ Total } & 3 & 14 & 0 & 17 & 100 & 7 & 10 & 17 & $100 \%$ \\
\hline
\end{tabular}

(Source: primary data, highway rensing, 28 October-5 December 2019)

From table 6 above, it is found that the frequency distribution of respondents in the control group before being given the most treatment was 9 female $(52.9 \%)$ with the most dominant risk falling category being $7(41.1 \%)$. Whereas for the respondents after being given the most treatment were 9 male $(52.9 \%)$ with the most dominant risk falling category being 6 people (35.2\%).

\section{Profession With Fall Incident}

a. Table 7 Cross Tabulation of Treatment Groups Based on Occupations with Falling Events Before

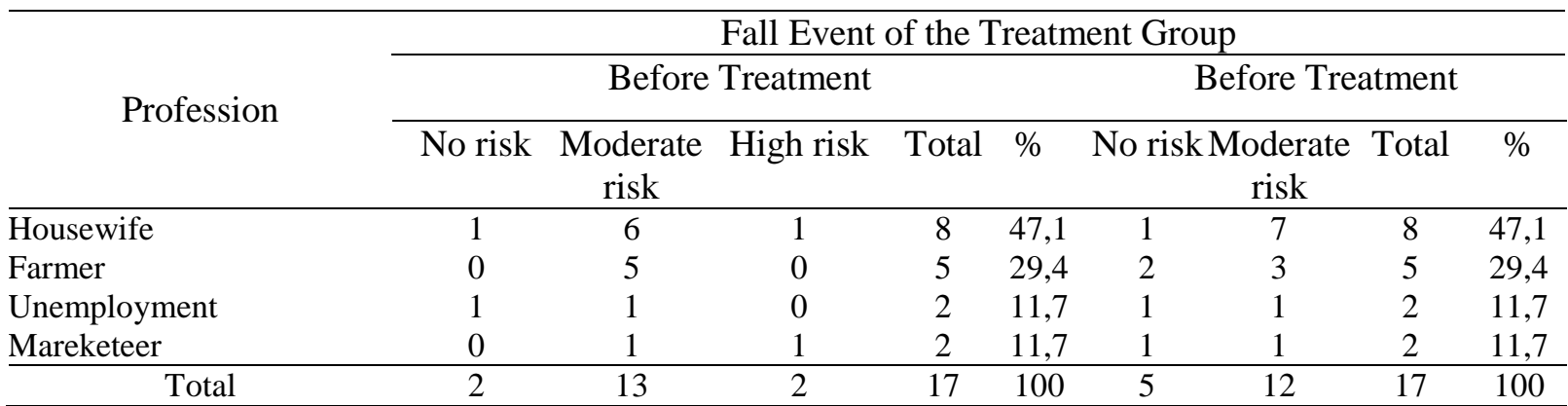

Treatment of the Elderly in Rensing Raya Village, West Sakra District, East Lombok Regency 2019. (Source: primary data, highway rensing, 28 October-5 December 2019)

From table 7 above, it is found that the frequency distribution of respondents in the treatment group prior to being given the most treatment is respondents who work as housewives totaling 8 people $(47.1 \%)$ with the category of falling events most dominantly at medium risk totaling 6 people $(35,2 \%)$. Whereas the respondent after being given the most treatment was the respondent whose occupation as a housewife was 8 people $(47.1 \%)$ with the most dominant risk falling category being 7 people $(41.1 \%)$.

b. Table 8 Cross Tabulation in Control Groups Based on Occupation with Falling Events Before Treatment of the Elderly in Rensing Raya Village, West Sakra District, East Lombok Regency 2019.

\begin{tabular}{|c|c|c|c|c|c|c|c|c|}
\hline \multirow{3}{*}{ Profession } & \multicolumn{8}{|c|}{ Fall Event of the Control Group } \\
\hline & \multicolumn{5}{|c|}{ Before Treatment } & \multicolumn{3}{|c|}{ Before Treatment } \\
\hline & No risk & $\begin{array}{l}\text { Moderate } \\
\text { risk }\end{array}$ & Total & $\%$ & No risk & $\begin{array}{l}\text { Moderate } \\
\text { risk }\end{array}$ & Total & $\%$ \\
\hline Worker & 0 & 4 & 4 & 23,5 & 3 & 1 & 4 & 23,5 \\
\hline Farmer & 2 & 2 & 4 & 23,5 & 3 & 1 & 4 & 23,5 \\
\hline marketeer & 0 & 1 & 1 & 5,8 & 0 & 1 & 1 & 5,8 \\
\hline Breeder & 1 & 1 & 2 & 11,7 & 0 & 2 & 2 & 11,7 \\
\hline Housewife & 0 & 5 & 5 & 29,4 & 0 & 5 & 5 & 29,4 \\
\hline
\end{tabular}




\begin{tabular}{cccccccccc} 
Officer & 0 & 1 & 1 & 5,8 & 1 & 0 & 1 & 5,8 \\
\hline & Total & 3 & 14 & 17 & 100 & 7 & 10 & 17 & 100 \\
\hline
\end{tabular}

(Source: primary data, highway rensing, 28 October-5 December 2019)

From table 8 above, it is found that the frequency distribution of respondents in the control group before being given the most treatment is respondents whose work as a housewife is 5 people (29.4\%) with the category of falling events most dominantly at medium risk of 5 people $(29,4 \%)$. Whereas the respondent after being given the most treatment was the respondent whose occupation was a housewife of 5 people $(29.4 \%)$ with the category of falling events being the most dominant being medium risk of 5 people $(29.4 \%)$.

\section{History of Disease With Fall Incident}

a. Table 9 Tabulasi Silang Pada Kelompok Perlakuan Berdasarkan Pekerjaan Dengan Kejadian Jatuh Sebelum Perlakuan Pada Lansia Di Desa Rensing Raya Kecamatan Sakra Barat Kabupaten Lombok Timur 2019.

\begin{tabular}{|c|c|c|c|c|c|c|c|c|c|}
\hline \multirow{3}{*}{ History of Disease } & \multicolumn{9}{|c|}{ Fall Event of the Treatment Group } \\
\hline & \multicolumn{5}{|c|}{ Before Treatment } & \multicolumn{4}{|c|}{ Before Treatment } \\
\hline & No risk & $\begin{array}{c}\text { Moderate } \\
\text { risk }\end{array}$ & High risk & Total & $\%$ & No risk & $\begin{array}{l}\text { Moderate } \\
\text { risk }\end{array}$ & Total & $\%$ \\
\hline$>1 \mathrm{di}$ & 2 & 10 & 2 & 14 & 82,4 & 5 & 9 & 14 & 82,4 \\
\hline 1 disease & 0 & 3 & 0 & 3 & 17,6 & 0 & 3 & 3 & 17,6 \\
\hline Total & 2 & 13 & 2 & 17 & 100 & 5 & 12 & 17 & 100 \\
\hline
\end{tabular}

(Source: primary data, highway rensing, 28 October-5 December 2019)

From table 9 above, it is found that the frequency distribution of respondents in the treatment group before being given the most treatment is respondents who have more than 1 disease totaling 14 people $(82.4 \%)$ with the most dominant risk falling category being 10 people $(58,8 \%)$. Whereas the respondent after being given the most treatment was those who had more than 1 disease totaling 14 people $(82.4 \%)$ with the category of falls being the most dominant risk being 9 people $(52.9 \%)$

b. Table 10 Cross Tabulation in Control Groups Based on Occupation with Falling Events Before Treatment of the Elderly in Rensing Raya Village, West Sakra District, East Lombok Regency 2019.

\begin{tabular}{|c|c|c|c|c|c|c|c|c|}
\hline \multirow{3}{*}{ History of Disease } & \multicolumn{8}{|c|}{ Fall Event of the Control Group } \\
\hline & \multicolumn{5}{|c|}{ Before Treatment } & \multicolumn{3}{|c|}{ Before Treatment } \\
\hline & No risk & $\begin{array}{l}\text { Moderate } \\
\text { risk }\end{array}$ & Total & $\%$ & No risk & $\begin{array}{l}\text { Moderat } \\
\text { risk }\end{array}$ & Total & $\%$ \\
\hline$>1$ disease & 2 & 10 & 12 & 70,5 & 4 & 8 & 12 & 70,5 \\
\hline 1 disease & 1 & 4 & 5 & 29,4 & 3 & 2 & 5 & 29,4 \\
\hline Total & 3 & 14 & 17 & 100 & 7 & 10 & 17 & 100 \\
\hline
\end{tabular}

(Source: primary data, highway rensing, 28 October-5 December 2019)

From table 10 above, it is found that the frequency distribution of respondents in the control group before being given the most treatment is respondents who have more than 1 disease totaling 12 people $(70.5 \%)$ with the most dominant risk falling category being 10 people $(58,8 \%)$. Whereas the respondent after being given the most treatment was those who had more than 1 disease totaling 12 people (70.5\%) with the category of the most dominant fall risk being 8 people (47.0\%).

\section{Data Normality Test}

1. Test Results of Falling Normality in the Treatment Group

Table 11 Results of Tests on the Occurrence of Occurrence in the Elderly in Rensing Raya Village, West Sakra District, East Lombok Regency 2019.

\begin{tabular}{l|l|c|c}
\hline \multicolumn{4}{c}{ One-Sample Kolmogorov-Smirnov Test } \\
\hline $\mathrm{N}$ & Fall Incident PRE & Fall Incident POST \\
\hline Normal Parameters & a,b & 17 & 17 \\
\hline
\end{tabular}




\begin{tabular}{l|l|c|c}
\hline & Std. Deviation & 16,213 & 10,598 \\
\hline \multirow{3}{*}{ Most Extreme Differences } & Absolute &, 194 &, 213 \\
\cline { 2 - 4 } & Positive &, 194 &, 213 \\
\cline { 2 - 4 } & Negative &,- 146 &,- 188 \\
\hline Kolmogorov-Smirnov Z &, 800 &, 879 \\
\hline Asymp. Sig. (2-tailed) &, 544 &, 422 \\
\hline a. Test distribution is Normal. & \multicolumn{2}{|l}{} \\
\hline
\end{tabular}

(Source: primary data processing results)

Based on table 11 above shows that the significance value of Asymp. Sig. (2-tailed) for falls before treatment is 0.544 , greater than 0.05 . Then according to the basis of decision making in the Kolmogorov-Smirnov $\mathrm{Z}$ normality test above it can be concluded that the data are normally distributed. As for the incidence of falls after being given a treatment of 0.422 , greater than 0.05 . Then according to the basis of decision making in the Kolmogorov-Smirnov $\mathrm{Z}$ normality test above it can be concluded that the data are normally distributed.

2. Test Results of Falling Normality in the Control Group

Table 12 Test Results of Falling Normality in the Elderly in Rensing Raya Village, West Sakra District, East Lombok Regency 2019.

\begin{tabular}{l|l|c|c}
\hline \multicolumn{4}{c}{ One-Sample Kolmogorov-Smirnov Test } \\
\hline $\mathrm{N}$ & Fall Incident PRE & Fall Incident POST \\
\hline \multirow{2}{*}{ Normal Parameters ${ }^{\mathrm{a}, \mathrm{b}}$} & Mean & 17 & 17 \\
\cline { 2 - 4 } & Std. Deviation & 32,65 & 23,53 \\
\hline \multirow{3}{*}{ Most Extreme Differences } & Absolute & 13,243 & 11,006 \\
\cline { 2 - 4 } & Positive &, 189 &, 212 \\
\cline { 2 - 4 } & Negative &,- 189 &, 212 \\
\hline Kolmogorov-Smirnov Z &, 740 &,- 168 \\
\hline Asymp. Sig. (2-tailed) &, 580 &, 872 \\
\hline a. Test distribution is Normal. & \multicolumn{3}{l}{} \\
\hline \multicolumn{2}{l}{ b. Calculated from data. }
\end{tabular}

(Source: primary data processing results)

Based on table 12 above shows that the significance value of Asymp. Sig. (2-tailed) for falls before treatment is given at 0.580 greater than 0.05 . Then according to the basis of decision making in the Kolmogorov-Smirnov $\mathrm{Z}$ normality test above it can be concluded that the data are normally distributed. As for the incidence of falls after being given a treatment of 0.432 , greater than 0.05 . Then according to the basis of decision making in the Kolmogorov-Smirnov $\mathrm{Z}$ normality test above it can be concluded that the data are normally distributed.

\section{Paired T-Test Test Results}

1. Falls Incident in the Treatment Group

Table 13 Paired T-Test Results of Falling Events in the Elderly in Rensing Raya Village, West Sakra District, East Lombok Regency 2019.

\begin{tabular}{|c|c|c|c|c|c|c|c|c|}
\hline 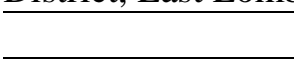 & & Paired & Sample & s Test & & & & \\
\hline & & Paired & Differen & aces & & $\mathrm{t}$ & $\mathrm{df}$ & Sig. (2 \\
\hline & Mean & $\begin{array}{c}\text { Std. } \\
\text { Deviation }\end{array}$ & $\begin{array}{l}\text { Std. } \\
\text { Error } \\
\text { Mean }\end{array}$ & $\begin{array}{l}95 \% \mathrm{Cc} \\
\text { Interv } \\
\text { Diff }\end{array}$ & $\begin{array}{l}\text { nfidence } \\
1 \text { of the } \\
\text { rence }\end{array}$ & & & \\
\hline $\begin{array}{l}\text { Pre Fall Incident - } \\
\text { Post Fall Incident }\end{array}$ & 10,882 & 14,168 & 3,436 & $\begin{array}{c}\text { Lower } \\
3,598\end{array}$ & $\begin{array}{l}\text { Upper } \\
18,167\end{array}$ & 3,167 & 16 & ,006 \\
\hline
\end{tabular}

(Source: primary data processing results) 
Based on table 13 above shows that there is a significant influence before and after the fall incident in the elderly by taking into account the results of statistical tests conducted by paired t-test to 17 respondents using 0.05 degree of error and the results obtained $p$ value of 0.006 . If the value of $p$ value <degree of error then the hypothesis is accepted. From the results of the above analysis it can be concluded that in the treatment group there is the effectiveness of physical exercise balance and muscle strength against the event of falling before and after being given treatment to the elderly

2. Falls Incident in the Control Group

Table 14 Results of Paired T-Test for Falling Events in the Elderly in Rensing Raya Village, West Sakra District, East Lombok Regency 2019.

\begin{tabular}{|c|c|c|c|c|c|c|c|c|}
\hline \multicolumn{9}{|c|}{ Paired Samples Test } \\
\hline & \multicolumn{5}{|c|}{ Paired Differences } & $\mathrm{t}$ & $\mathrm{df}$ & Sig. (2-tailed) \\
\hline & Mean & $\begin{array}{l}\text { Std. } \\
\text { Deviation }\end{array}$ & $\begin{array}{l}\text { Std. } \\
\text { Error } \\
\text { Mean }\end{array}$ & $\begin{array}{l}95 \% \mathrm{C} \\
\text { Interva } \\
\text { Differe }\end{array}$ & $\begin{array}{l}\text { fidence } \\
\text { of the } \\
\text { ce }\end{array}$ & & & \\
\hline Pre Fall Incident - & & & & Lower & Upper & & & \\
\hline Post Fall Incident & 3,824 & 6,002 & 1,456 & ,737 & 6,910 & 2,626 & 16 & ,018 \\
\hline
\end{tabular}

(Source: primary data processing results)

Based on table 14 above shows that there is a significant influence before and after the treatment of falling events in the elderly by taking into account the results of statistical tests conducted by paired t-tests to 17 respondents using 0.05 degree of error and the results obtained $p$ value of 0.018 . If the value of $\mathrm{p}$ value < degree of error then the hypothesis is accepted. From the results of the above analysis it can be concluded that the control group had an influence on the incidence of falls before and after being given the elderly gymnastics

\section{DISCUSSION}

\section{Physical Exercise Body Balance Before And After Treatment}

Based on the results of the study that in the treatment group before being given physical exercise the most balance was respondents with moderate risk categories totaling 13 people $(76.5 \%)$. Whereas after being given balance physical exercise the most were respondents in the moderate risk category to fall totaling 12 people $(70.6 \%)$.

Balance is the ability to maintain body balance when changing positions. If the balance of the body is not trained in the elderly it will cause major problems in the quality of life of the elderly such as falls and result in injury.

Balance exercise is one of the exercises that can be applied to the elderly. This exercise is a physical activity that is done to improve the stability of the body by increasing muscle strength in the legs. This exercise will train the body's buffer base so that postural balance will be formed. This balance exercise consists of 5 movements that involve the soles of the feet, knees, thighs, and hips. The elderly are advised to do 3 times a week with a duration of 30 minutes (elfiana elida et al 2019).

The difference in test results before and after balance training in the elderly with the influence between the risk of falling with the elderly residence cannot be separated from intrinsic or extrinsic factors that can affect balance disorders and the incidence of falls. Impaired balance is influenced by various factors such as age, body's gravity point, body's gravity line, pedestal point, and muscle strength. There are intrinsic, extrinsic, and situational factors that influence falls. Intrinsic factors include physical conditions, neurospychiatry, decreased vision and hearing, neuromuscular changes, gait, and postural reflexes. Extrinsic factors that influence for example environmental conditions, walking aids, and consumption of drugs such as antidepressants and diuretic drugs. While situational factors such as a history of disease and activity (Darmojo, 2011).

Body balance in the elderly can be influenced by age. In this study the age of the treatment group respondents before being given the most treatment was age 60-74 years with a moderate risk category for experiencing a fall. Whereas after being given the most treatment is the age of 60-74 years with a moderate risk category to experience a fall event. Besides being influenced by age, gender can also 
affect the incidence of falls in the elderly. From the results obtained in this study, in the treatment group before being given balance physical exercise, the majority of women were more males than men with the most dominant category being at moderate risk of falling and after being given the treatment in the form of body balance exercises the most were women. Other factors that can affect the balance of the body resulting in falls in the elderly are the type of work among the community where the study. In the research results, the majority of the treatment group and the majority control group were occupational status as housewives or not working. In the treatment group before being given balance physical exercise, there were a number of elderly people who were at high risk for falling but after being given balance physical exercise there was a decrease in the number of elderly people so that there were no elderly people who were at high risk. Likewise with the control group that before the elderly exercise many experienced moderate risk to fall but after the elderly exercise decreased the number of elderly at moderate risk. Other factors that can affect the balance of the body resulting in falls in the elderly are the type of work among the community where the study. In the research results, the majority of the treatment group and the majority control group were occupational status as housewives or not working. In the treatment group before being given balance physical exercise, there were a number of elderly people who were at high risk for falling but after being given balance physical exercise there was a decrease in the number of elderly people so that there were no elderly people who were at high risk. Likewise with the control group that before the elderly exercise many experienced moderate risk to fall but after the elderly exercise decreased the number of elderly at moderate risk.

At the age of 60-74 years, they tend to experience balance disorders, so they are susceptible to falling in the elderly to cause minor or severe injuries. In contrast to the results of research conducted by Barnedh (2006) setyoadi et al (2013) that the proportion in the age group over 80 years will experience a balance disorder of $70 \%$. Therefore, researchers assume that increasing age accompanied by a decrease in the musculoskeletal system due to aging can affect the body's balance and muscle strength because in the lower extremities there is a decrease in muscle strength resulting in changes in balance to support body weight and a greater risk of falling. Researchers also assume that there is a decrease in the number of elderly people who experience falls. Where before being given treatment, there are elderly people who have a high risk of falling. and after being given treatment to the elderly, those at high risk can improve their balance so that they are in the medium risk category to fall. In general, men are stronger than women. This is due to differences in muscle mass between men and women. Therefore, women will be more at risk of falling, especially in the elderly. A similar study conducted by Santoso found an average value of $1 \mathrm{RM}$ for males at $17.13 \mathrm{~kg}$ while $1 \mathrm{RM}$ for women at $13.62 \mathrm{~kg}$. Based on the description above, researchers assume that in the treatment group there was a decrease in the amount after being given balance training. Before giving balance training, there were elderly people who were at high risk for falling and after being given balance training there were no elderly people who were at high risk for falling. While in the control group before and after gymnastics, the majority are male, and there is a slight change in the decrease in the number with a moderate risk category for experiencing a fall. So, women are more at risk of falling than men. In general, work is very closely related to daily activities. In the publication publication Firda D.A (2017) said that physical activity has a positive effect on muscle strength and prevents progressive muscle weakness in the elderly. Therefore the researchers assume that, if the elderly continue to carry out their daily activities in accordance with the existing activities of the bimbi hamlet rensing raya village such as balance training and muscle strength twice a week, gardening, recitation activities, happy stage, and skills as well as conducting balance exercises in a manner regularly is expected to increase the strength of the lower extremities and balance so as to prevent the risk of falls

\section{Muscle Strength Training Before And After Treatment}

Based on the results of the study that in the treatment group before being given physical exercise the most balance was respondents with moderate risk categories totaling 13 people $(76.5 \%)$. Whereas after being given balance physical exercise the most were respondents in the moderate risk category to fall totaling 12 people (70.6\%). There was a decrease in the number of elderly people who previously had 2 elderly people at high risk for falls, but after being given muscle strength training there was no high risk for falls. Whereas in the control group before being given the elderly exercise the most was at moderate risk to experience a fall of 14 people (82.4\%). Whereas after being given the most elderly 
gymnastics is in the medium risk category to experience a fall of 10 people (58.8\%). The results of this study indicate that the muscle strength of men and women is different in general, so women are more likely to experience falls.

According to Janssen (2010, in Utomo 2010), muscle strength is an exercise in muscle strength or muscle groups produced to be able to fight prisoners with maximum effort. Muscle strength is a physical exercise that is very important for everyone, because muscle strength is a driving force of movement in completing tasks and can reduce falls especially for the elderly.

The same thing was stated based on research by Santoso in the journal Prisilia et al (2015) found an average value of $1 \mathrm{RM}$ in men is $17.13 \mathrm{~kg}$ while the average value of $1 \mathrm{RM}$ in women is $13.62 \mathrm{~kg}$. That way, the value of $1 \mathrm{RM}$ of quadriceps femoris muscle according to sex shows the value of $1 \mathrm{RM}$ in men is greater than in women. In general, men are stronger than women. That was caused by differences in muscle mass. This increase in strength is related to the increase in muscle mass after puberty, because after puberty the muscle mass of men is $50 \%$ greater than the muscle mass of women.

Based on the findings obtained during muscle strength training in the elderly, in the stages of shoulder flexion, shoulder abduction and adduction, shoulder internal and external rotation, shoulder adduction crossing, supination and pronation of the arms, extension and flexion of the wrist and fingers, flexion and extension of the mother finger, hip and knee flexion and extension, pelvic internal and external rotation, pelvic abduction and adduction, dorso and plantar ankle flexion, eversion and inversion of the foot, toe extension and flexion of the toes are found in elderly muscle movements so there is muscle stiffness so much elderly complain of pain when moved. But it is slowly there is flexibility between the muscles after doing the exercise. Similar to the control group given elderly exercise, it was found that some of the elderly were unable to do elderly exercise because their limbs had never been carried out. Nevertheless the elderly try to do gymnastics elderly so slowly the elderly can do elderly gymnastics. Based on the description above, researchers assume that in an effort to reduce the risk of falls in the elderly can be done by physical exercise routinely and continuously strength of the muscles so as to improve the balance of the body in the elderly. Thus it is likely to experience a decrease in the incidence of falls in the elderly. Therefore, a strong social support system is needed from the local government in making policies to run a routine program of muscle strength training and balance training in improving physical exercise in the elderly, safe environment, falling risk assessment, and providing competent human resources. in preventing falls.

\section{Physical Exercise Balance and Muscle Strength Against Fall}

Based on the results of the study that in the treatment group before being given physical exercise the most balance was respondents with moderate risk categories totaling 13 people $(76.5 \%)$. Whereas after being given balance physical exercise the most were respondents in the moderate risk category to fall totaling 12 people $(70.6 \%)$.

Basically, the elderly experience physical and psychological changes, one of which is the musculoskeletal system in which the bones are increasingly fragile, bone strength and stability decreases, kifosis occurs, changes in gait, atrophy of muscle fibers so that movement becomes slow. These changes can result in sluggish motion, short footsteps, decreased power, decrepit easily swaying so that they experience impaired balance and eventually risk falling (Potter \& Perry, 2006). So, balance is the ability to maintain body balance when changing positions. If the balance of the body is not trained in the elderly, it will cause major problems in the quality of life of the elderly, such as falls and resulting injuries (Setiawan, 2007).

From the results of previous studies, researchers agree that physical exercise balance and muscle strength training can reduce the risk of falls in the elderly. At the time the researchers conducted the exercise activity for 8 weeks, it was found that the elderly before being given training in the category of no-risk amounted to 2 people, moderate risk amounted to 13 and a high risk of 2 people against falling events, but after being given training can reduce the number of elderly people who were not 5 people are at risk, 12 are at moderate risk and there is no high risk. From this the researchers assume that balance training and muscle strength are very effective in reducing the incidence of falls in the elderly. While in the control group given elderly exercise also has the effectiveness to reduce the incidence of falls in the elderly, but based on the phenomena obtained at the time of the study there were some elderly who were unable to do gymnastic activities due to their decreased muscle strength 
and balance. Therefore, researchers assume that between balance training, muscle strength (for the treatment group) and elderly exercise for (the control group) it should be done gradually starting with balance training and muscle strength training first, then the elderly exercise.

\section{CONCLUSION}

1. There is an effectiveness of physical exercise for the elderly's body balance on the occurrence of falls in the treatment group where the change in the average body balance of the elderly is very meaningful so that it can reduce the incidence of falls in the elderly even though it is still in the medium risk category to experience a fall.

2. There is an effectiveness of elderly muscle strength training on falling events in the treatment group where after given balance training continued to provide muscle strength training can reduce the incidence of falls in the elderly even though it is still in the medium risk category for falls.

3. In the control group that is directly given the elderly exercise activities can also reduce the risk of experiencing a fall event even though it is still in the medium risk category but there is a change where before the elderly exercise that is not at risk as many as 3 people and after the elderly exercise increases to 7 people. This is because it does not warm up before doing gymnastics.

4. The majority of respondents in this study were elderly aged 60-74 years with the most sex being women who lack physical activity.

Physical exercise for body balance, muscle strength training, and also gymnastics for the elderly can reduce the number of falls, but in carrying out these activities must be carried out in a structured manner covering the first step that must be done is physical exercise balance then then do muscle strength training and the last to do elderly gymnastics.

\section{REFERENCES}

Alvita,G.W., Huda, S. 2018, Pengaruh Senam Keseimbangan Dengan Resiko Jatuh Pada Lansia Di Unit Rehabilitasi Sosial Margomukti Rembang, Prosiding Health Event of All, P-ISSN 25812270, E- ISSN 2614-6401.

Arikunto, S. (2012). Prosedur Penelitian. Rineka Cipta, Jakarta

Avelar. 2010. Effectiveness of Aquatic and Non-Aquatic Lower Limb Muscles Endurance Training in The Static and Dynamic Balance of Elderly People: Revista Brasileira de Fisioterapia, vol. 14.

Balzer, K., Bremer, M., Schramm, S., Luhman, D., Raspe, H.,2012, Falls prevention for the elderly, GMS Health Technology Assessment 2012, Vol. 8, ISSN 1861-8863.

Biro Pusat Statistik (2017). Sensus Penduduk Indonesia. Jakarta: EGC

BPS (2018). Penduduk Lanjut usia. http://www.menegpp.go.id/V2/Index(php)/datadaninformasi/kependudukan

Budi Utomo, Sukadarwanto, M.Mudatsir Syatibi 2015, Peningkatan Kecepatan Jalan Dan Keseimbangan Usia Lanjut Menggunakan Model Aquatic Exercise Dan Land Exercise Therapy.

Budi Utomo, Yulianto Wahyono, Nawangsasi Takarini 2012, Peningkatan Kekuatan, Fleksibilitas Dan Keseimbangan Otot Lanjut Usia Melalui Senam Mandiri.

Dharmojo. 2011. Geriatri (Ilmu Kesehatan Usia Lanjut). Jakarta: Balai FKUI

Galia Wardha Alvita, Solikhul Huda, 2018, Pengaruh Senam Keseimbangan Dengan Resiko Jatuh Pada Lansia Di Unit Rehabilitasi Sosial Margomukti Rembang.

Jeon, M.Y.,Gu, M.O.,Yim, J. 2017, Comparison of Walking, Muscle Strength, Balance, and Fear of Falling Between Repeated Fall Group, One-time Fall Group, and Nonfall Group of the Elderly Receiving Home Care Service, Asian Nursing Research 11 (2017) 290e296.

Josse, A., Parraca., Pedro, R. O., Ana, C.B., Virginia, A.A., Jose, C. A., Gusi, N. 2011, Test-Retest reliability of Biodex Balance SD on physically active old people, Journal Of Human Sport \& Exercise Issn 1988-5202.

Martono \& Darmojo. 2004. Buku Ajar Geriatri (Ilmu Kesehatan Usia Lanjut).Jakarta: FKUI.

Miller, C.A. 2004. Nursing for Wellnes in Older Adults Theory and Practice. (4th Edition). Philadelphia: lippincott Williams \& Wilkins.

NANDA International, Inc. 2014. Nursing Diagnoses: Definitions and Classification 2015-2017.

Notoadmodjo, S (2010). Metodologi Penelitian Kesehatan. Jakarta: Rineka Cipta. 
Prisilia M. Pinontoan, Sylvia R. Marunduh, Herlina I. S. Wungouw 2015, Gambaran Kekuatan Otot Pada Lansia Di Bplu Senja Cerah Paniki Bawah

Setyoadi, Yulian Wiji Utami, Sheylla Septina M 2013, Senam Dapat Meningkatkan Keseimbangan Tubuh Lansia Di Yayasan Gerontologi Kecamatan Wajak Kabupaten Malang.

Stanley, M. 2006. Buku Ajar Keperawatan Gerontik. Jakarta: EGC.

Sugijanto (2017). Efek Pealtihan Senam Lansia dan Latihan Jalan Tandem Dalam Meningkatkan Keseimbangan Tubuh Lansia di Panti Sosial Tresna.

http://eprints.ums.ac.id/50844/2/02.NASKAH\%20PUBLIKASI.pdf

http://lib.ui.ac.id/naskahringkas/2018-09/S61171-Uswatun\%20Hasanah

http://eprints.ums.ac.id/50917/1/NASKAH\%20PUBLIKASI\%20FIX.pdf

http://repository.uinjkt.ac.id/dspace/bitstream/123456789/30621/1/PERMATA\%20HIDAYAT\%20A SHAR-FKIK.pdf

Sedeghi, H., Amri, S.B., Razeghi, M., Hamid, T.A., Hakim Abdullah, M.N. 2017, Effects of Combined exergame and conventional exercise to reduce and prevent fall risk among elderly people: A Hypothesis, International Journal of Applied Exercise Physiology, 2322-3537.

Yang, N.P.,His, N.W., Lin, C.H., Chen, H.C., Tsao, H.M., Lo,S.S., Chou, P., 2018, Relationship between muscle strength and fall episodes among the elderly: the Yilan study, Taiwan, Yang et al. BMC Geriatrics (2018) 18:90 https://doi.org/10.1186/s12877-018-0779-2.

Pinontoan, P.M., Marunduh, S.R., Wungouw, H.I.S. 2015, Gambaran Kekuatan Otot Pada Lansia Di Bplu Senja Cerah Paniki Bawah, Jurnal e-Biomedik (eBm), Volume 3, Nomor 1, Januari-April 2015.

Setyoadi., Utami, Y.W., Sheylla, S.M. 2013, Senam Dapat Meningkatkan Keseimbangan Tubuh Lansia Di Yayasan Gerontologi Kecamatan Wajak Kabupaten Malang, Jurnal Ilmu Keperawatan, Vol: I, No.1, Mei 2013, ISSN:2088-6012.

Utomo, B., Sukadarwanto., Syatibi, M.M. 2015, Peningkatan Kecepatan Jalan Dan Keseimbangan Usia Lanjut Menggunakan Model Aquatic Exercise Dan Land Exercise Therapy, Jurnal Terpadu Ilmu Kesehatan, Volume 4, No 2,November 2015.

Utomo, B., Wahyono, Y., Takarini, N. 2012, Peningkatan Kekuatan, Fleksibilitas Dan Keseimbangan

Otot Lanjut Usia Melalui Senam Mandiri, Jurnal Terpadu Ilmu Kesehatan, Jilid 2, 